RESEARCH Note

\title{
Development of six novel microsatellite markers for the Chilean red alga Pyropia orbicularis
}

\author{
Desarrollo y caracterización de seis marcadores microsatélites para el alga roja chilena \\ Pyropia orbicularis
}

\section{Gabriel Pérez-Lara ${ }^{1,2}$, Andrés Meynard ${ }^{1,2,3}$, Paula Alvear ${ }^{1}$, Cristian Bulboa- Contador $^{1,2}$ and Loretto Contreras-Porcia ${ }^{1,2,3^{*}}$}

\author{
${ }^{1}$ Departamento de Ecología y Biodiversidad, Facultad de Ciencias de la Vida, Universidad Andres Bello, República 440, Santiago, Chile \\ ${ }^{2}$ Centro de Investigación Marina Quintay (CIMARQ), Facultad de Ciencias de la Vida, Universidad Andres Bello, Ex Ballenera de \\ Quintay s/n, Quintay, Chile \\ ${ }^{3}$ Center of Applied Ecology and Sustainability (CAPES), Santiago, Chile \\ *Corresponding author: lorettocontreras@unab.cl
}

\begin{abstract}
Mariculture of edible Porphyra/Pyropia species, which are cosmopolitan red foliose algae, represent an important source of income for the pharmaceutical and food industries. In Chile, the most common alga of this complex is Pyropia orbicularis (Bangiales, Rhodophyta). Here we report 6 microsatellite markers obtained from $P$. orbicularis through a genomic library from 10 individuals of the gametophytic phase by next generation (Illumina) sequencing. Polymorphism analyses were done from 10 individuals of the conchocelis phase, revealing an allelic diversity ranging from three to six alleles per locus, and observed heterozygosity (HO) and expected heterozygosity $(\mathrm{HE})$ ranging from 0.200 to 0.995 , and 0.250 to 0.610 , respectively. A large proportion of genetic variance $(61 \%)$ in $P$. orbicularis was among individuals within population, and $39 \%$ genetic variance was among populations. Nonetheless, these results should be interpreted with caution; further research using larger sample sizes is required. These polymorphic markers could be useful in future studies on population genetic structure, for conservation and applied purposes.
\end{abstract}

Key words: Pyropia orbicularis, microsatellite markers, Rhodophyta

\section{INTRODUCTION}

A recent research on the Bangiales order (Rhodophyta) based on the mitochondrial $\mathrm{COI}$ and chloroplastal $r b c \mathrm{~L}$ genes, found 18 new species along the Chilean coast (1 belonging to the Wildemania genus, 1 to Fuscifolium, 8 to Porphyra, and 8 to Pyropia) (Guillemin et al. 2016). Worth highlighting among these new Chilean species is Pyropia orbicularis. This alga is widely distributed along the Chilean coastline, extending from $32^{\circ} \mathrm{S}$ to $53^{\circ} \mathrm{S}$, making it the most conspicuous foliose species of the Bangiales order in Chile (Ramírez et al. 2014, Guillemin et al. 2016). P. orbicularis primarily inhabits the upper intertidal zone (Meynard et al. 2019), where this alga is able to acclimate to long periods of desiccation and rehydration during daily tide cycles (Contreras-Porcia et al. 2011). This high plasticity has made this species a biological model on oxidative stress and desiccation tolerance (Contreras-Porcia et al. 2013, López-Cristoffanini et al.
2015, Guajardo et al. 2016, Fierro et al. 2017). It is worth mentioning that in Asia Pyropia/Porphyra species are intensively cultivated for dietary ends, generating revenues of $\approx$ US $\$ 1.3$ billion/year (Blouin et al. 2011).

Given the potential socio-economic benefits of $P$. orbicularis derived products to coastal communities, the food and biotechnological industries, there is a need to develop genetic markers for the evaluation of the genetic diversity of this species. The present study addresses this knowledge gap in the Southeast Pacific by developing 6 microsatellite markers for $P$. orbicularis and evaluating their polymorphism. As previously demonstrated by studies using this type of markers, these microsatellite could be useful in studies of population genetic structure (Becerra \& Paredes 2000, Aranguren-Méndez et al. 2005), evolutionary processes (Zuo et al. 2007), and in studies having applied or conservation purposes. 


\section{MATERIALS AND METHODS}

To construct the genomic library, 10 individuals of the gametophytic phase of $P$. orbicularis (Fig. 1) were collected from the rocky intertidal zone of Maitencillo beach, in central Chile $\left(32^{\circ} 38^{\prime} 57^{\prime \prime} \mathrm{S} ; 71^{\circ} 26^{\prime} 34^{\prime \prime} \mathrm{W}\right)$. Genomic DNA was extracted following methods reported by Wattier et al. (2000). Libraries and sequencing were performed in the core research facilities AUSTRAL-omics of the Universidad Austral de Chile (Valdivia, Chile). Five hundred ng of a DNA mix of 6 gametophytic individuals was fragmented to the desired length (200-1200 bp), and amplified by PCR to construct the genomic library using the Illumina Nextera ${ }^{\circledR}$ XT DNA Library Preparation Kit. The obtained fragments of interest were between 410 and $480 \mathrm{bp}$. The final concentration of the library was estimated through quantitative PCR (qPCR) in a LightCycler ${ }^{\circledR}$ Nano System (Roche) and using the KAPA Quantification Kit (Illumina Sequencing Platforms). Sequencing was performed using the MiSeq Reagent Kit v2 (500 cycles). Microsatellites were identified using the QDD pipeline program (Meglécz et al. 2014). Reads having at least 95\% identity were clustered as consensus sequences, while those which could not be grouped where classified as singletons, using Blast+ (Camacho et al. 2009). Potential primers were designed using the PRIMER v3.0 software (Rozen \& Skaletsky 2000). Primers were mainly selected according to the type and size of the repeated motifs, and the base composition of the flanking regions. Primer selection included also the following criteria: primer length close to $20 \mathrm{bp}$; 50 to $75 \%$ GC content; a distance greater than 20 bp between the primer motif and the repeated motif; and amplicon sizes between $100 \mathrm{bp}$ and $500 \mathrm{bp}$.

Each amplification test for the 6 loci was conducted using 10 in vitro cultivated conchocelis-stage of $P$. orbicularis. Each conchocelis sample was obtained from the cultivation of zygotoespores coming from $1 \mathrm{~cm}$ piece of a single gametophytic blade. Five gametophytic blades were collected at the rocky intertidal zones of Maitencillo and

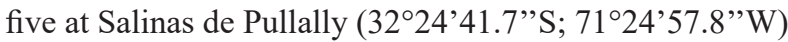
in Central Chile. Amplification of the microsatellites loci was done by PCR using the M13-tailed primer method, including fluorophores complementary to the forward primer. The 6 microsatellite loci were evaluated through PCR in a final reaction volume of $15 \mu \mathrm{L}$, which contained 10-20 ng of DNA template. Each reaction contained 0.15 $\mu \mathrm{M}$ of each primer, $2 \mathrm{mM}$ of $\mathrm{MgCl}_{2}, 0.15 \mathrm{mM}$ of dNTPs, $1 \mathrm{X}$ of colorless GoTaq flexi buffer, and $0.35 \mathrm{U}$ of GoTaq G2 flexi DNA polymerase. Ultrapure water was added to obtain the final reaction volume. PCR amplifications were conducted on a StepOnePlus ${ }^{\text {TM }}$ Real-Time PCR System (Applied Biosystems) with the following thermocycler conditions: initial denaturalization at $95{ }^{\circ} \mathrm{C}$ for $5 \mathrm{~min}$,
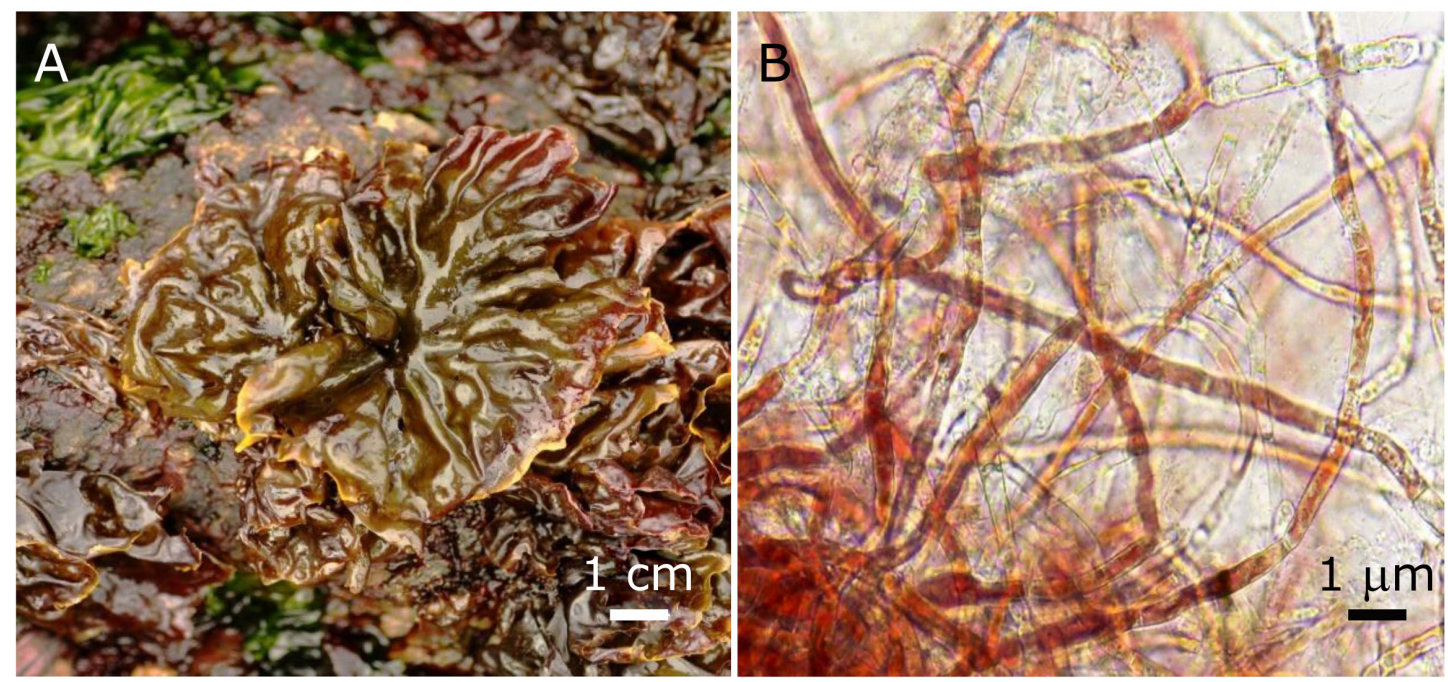

Figure 1. A) Gametophytic phase of $P$. orbicularis used for the creation of the genomic library. B) Conchocelis phase of $P$. orbicularis used for loci evaluation by PCR / A) Fase gametofítica de $P$. orbicularis usado para la creación de la librería genómica. B) Fase conchocelis de $P$. orbicularis usada para la evaluación de los loci a través de PCR 
followed by 40 cycles at $95^{\circ} \mathrm{C}$ for $30 \mathrm{~s}, 55-60^{\circ} \mathrm{C}$ for $30 \mathrm{~s}$ (see Table 1 for specific annealing temperatures of each locus), $72{ }^{\circ} \mathrm{C}$ for $30 \mathrm{~s}$, and a final extension at $72{ }^{\circ} \mathrm{C}$ for $5 \mathrm{~min}$. The amplified products were resolved on a $10 \%$ non-denaturing polyacrylamide gel, stained with GelRed and visualized under UV. PCR products were run on an ABI Prism 310 Genetic Analyzer. Alleles of P. orbicularis were identified using the software GeneMarker ${ }^{\circledR}$ (Hulce et al. 2011) (Fig. 2). Population genetic diversity indexes (allelic diversity, heterozygocity), inbreeding coefficient $\left(\mathrm{F}_{\mathrm{IS}}\right)$ and genetic distance between the two populations were calculated using the software GenAlEx 6.5 (Peakall \& Smouse 2006, 2012). Linkage disequilibrium (LD) and Hardy-Weinberg equilibrium (HWE) were calculated using GENEPOP 4.2 (Raymond \& Rousset 1995).

\section{RESULTS AND DISCUSSION}

A total read of $8,571,507$ bp was obtained, in which more than 5,000 microsatellites were found. Initially, 13 microsatellites markers were constructed that fulfilled the selection criteria previously mentioned. Nonetheless, only 6 pairs of these microsatellite primers were used to analyze the polymorphisms of the conchocelis phase of Pyropia orbicularis. This was done because technical problems were experienced to obtain enough biomass of the cultivated conchocelis for DNA extraction from all samples (only 5 out of the 20 samples originally cultivated per site). Some characteristics of the 6 microsatellite loci are indicated in Table 1. Results showed that the 6 loci had 3-6 alleles per locus and observed and expected heterozygosities ranging from 0.200 to 0.995 , and 0.250 to 0.610 , respectively. Significant heterozygote deficiency was observed for locus Orb6 in Maitencillo $(P<0.05)$. Linkage disequilibrium calculations for each locus pair indicated that loci are not in linkage disequilibrium. According to the coefficient of gene differentiation (Gst) a large proportion of genetic variance $(61 \%)$ in $P$. orbicularis was among individuals within population, and 39\% genetic variance was among populations, suggesting an important level of differentiation between the two sites distant about $35 \mathrm{~km}$ apart. The $\mathrm{F}_{\text {IS }}$ for each locus was significantly different from zero and ranged from -0.670 to 0.380 (Table 1 ). In the two sampling sites, some significant negative $\mathrm{F}_{\mathrm{IS}}$ values were observed, such as at loci Orb7 and Orb8, suggesting a heterozygote excess; on

Table 1. Primers sequences and optimum annealing temperature (Ta) for six microsatellite loci from Pyropia orbicularis / Secuencias de los partidores utilizados y temperatura óptima de annealing (Ta) para seis loci microsatélites de Pyropia orbicularis

\begin{tabular}{|c|c|c|c|c|c|c|c|c|}
\hline $\begin{array}{l}\text { Locus } \\
\text { name }\end{array}$ & Primer sequence & $\begin{array}{l}\text { Repeat } \\
\text { motif }\end{array}$ & $\begin{array}{l}\text { Size } \\
(b p)\end{array}$ & $\begin{array}{c}\mathrm{Ta} \\
\left({ }^{\circ} \mathrm{C}\right)\end{array}$ & $\begin{array}{l}\text { No. of } \\
\text { alleles }\end{array}$ & $\mathrm{HO} / \mathrm{HE}$ & Fis & $\begin{array}{c}\text { GenBank } \\
\text { Accession no. }\end{array}$ \\
\hline Orb1 & $\begin{array}{l}\text { F: GCATGCTGACAGAAAGACGA } \\
\text { R: GTATTGTGCGACCTTGCGTT }\end{array}$ & $(\mathrm{CAGC})_{5}$ & $\begin{array}{l}101 \\
135\end{array}$ & $\begin{array}{l}60 \\
61\end{array}$ & 6 & $\begin{array}{l}0.330 \\
0.490\end{array}$ & 0.259 & MN449481 \\
\hline Orb5 & $\begin{array}{l}\text { F: CAGTGATTGGAGTGGCTCAG } \\
\text { R: TTTGTCCGTTAAACCAGACG }\end{array}$ & $(\mathrm{AGA})_{9}$ & $\begin{array}{l}190 \\
303\end{array}$ & $\begin{array}{l}59 \\
59\end{array}$ & 6 & $\begin{array}{l}0.260 \\
0.320\end{array}$ & 0.153 & MN449482 \\
\hline Orb6 & $\begin{array}{l}\text { F: TCTGTGGGATATGGAGGCAT } \\
\text { R: ACAAGTTTGTGTCGAGrCGAA }\end{array}$ & $(\mathrm{AC})_{36}$ & $\begin{array}{l}185 \\
257\end{array}$ & $\begin{array}{l}60 \\
60\end{array}$ & 5 & $\begin{array}{l}0.248 \\
0.372\end{array}$ & 0.312 & MN449483 \\
\hline Orb7 & $\begin{array}{l}\text { F: CGAGGAGTGTACAGAGGGACA } \\
\text { R: GGATATAGACGGCATCGAACA }\end{array}$ & $(\mathrm{TTG})_{13}$ & $\begin{array}{l}252 \\
275\end{array}$ & $\begin{array}{l}60 \\
60\end{array}$ & 3 & $\begin{array}{l}0.940 \\
0.550\end{array}$ & $\overline{-}-\overline{670}$ & MN449484 \\
\hline Orb8 & $\begin{array}{l}\text { F: CCTCTCCTACTGCCTTCACG } \\
\text { R: ATCGCATTTCAGCATTATCG }\end{array}$ & $\left(\mathrm{TGAA}_{6}\right.$ & $\begin{array}{l}234 \\
286\end{array}$ & $\begin{array}{l}60 \\
59\end{array}$ & 3 & $\begin{array}{l}0.995 \\
0.500\end{array}$ & 0.327 & MN449485 \\
\hline Orb9 & $\begin{array}{c}\text { F: TCAGGGTCAACAGTGTCCTC } \\
\text { R: CACAAGGATAAAGATTTAAGGCAAA }\end{array}$ & $(\mathrm{TC})_{22}$ & $\begin{array}{l}316 \\
338\end{array}$ & $\begin{array}{l}59 \\
60\end{array}$ & 4 & $\begin{array}{l}0.426 \\
0.829\end{array}$ & 0.380 & MN449486 \\
\hline
\end{tabular}

FIS: inbreeding coefficient, HO: observed heterozygosity, HE: expected heterozygosity 


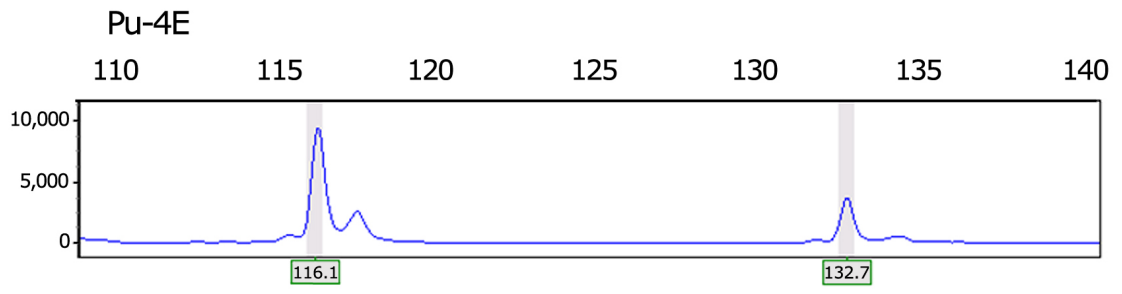

Mai-15

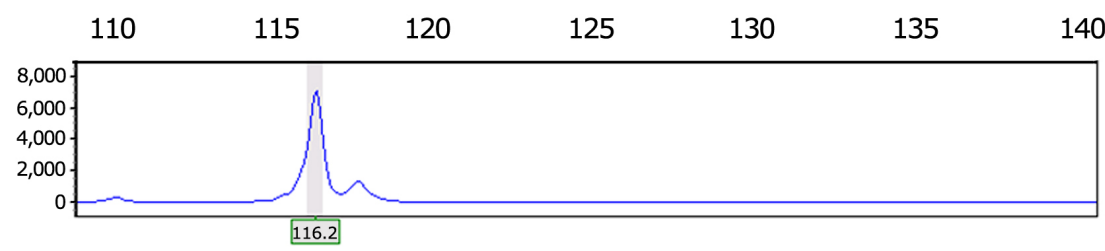

Mai-11

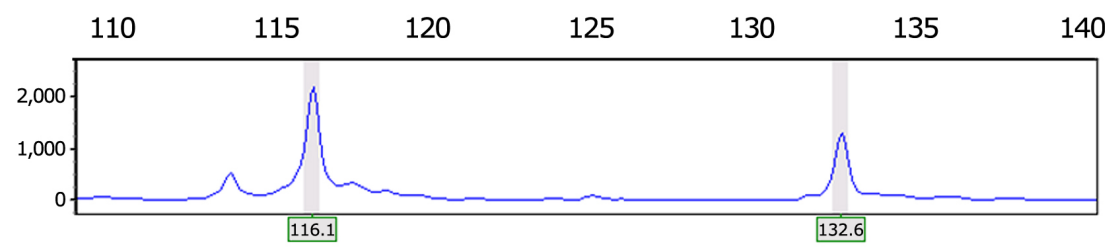

Mai-8

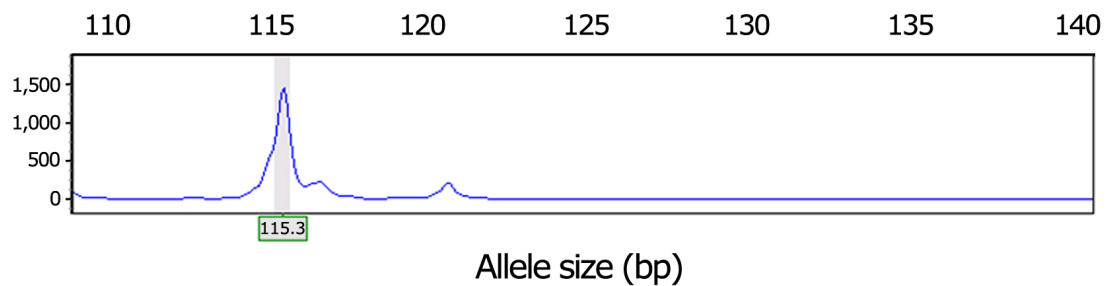

Figure 2. Analysis of genomic fragments from locus Orb1 using samples of Pyropia orbicularis from Maitencillo (Mai 8, 11 and 15) and Salinas de Pullally (Pu 4E) employing the software GeneMarker v 1.75 (SoftGenetics LLC, State College, PA, USA). Two homozygous and two heterozygous individuals are observed for this microsatellite / Análisis de fragmentos para el locus Orb1 en muestras de Pyropia orbicularis provenientes de Maitencillo (Mai 8, 11 y 15) y Salinas de Pullally (Pu 4E) empleando el programa GeneMarker v 1.75. Se observan dos individuos homocigotos y dos heterocigotos para este microsatélite

the contrary, high positive $\mathrm{F}_{\text {IS }}$ values were observed at the other loci, suggesting inbreeding or selection. Nonetheless, results should be interpreted with caution due the small sample sizes. Indeed, HWE, LD, $\mathrm{F}_{\text {IS }}$ and Gst should be re-calculated using larger sample sizes to confirm these results. On the other hand, taking into consideration the technical problems previously mentioned; genetic polymorphism determination at the population level would have ideally to use samples from the gametophytic phase rather than the conchocelis phase. Since the gametophytic phase has been demonstrated to be a genetic chimera (Yan \& Huang 2010); a very restricted tissue area of the gametophytic blade would have to be selected for DNA extraction; this, in order to avoid the mix of genetic material from genetically different sectors of the blade.

The 6 microsatellite primers pairs proposed herein for Pyropia orbicularis are the first to be published for this commercially relevant alga. These microsatellite primers are sufficiently variable for the study of genetic structure, and will facilitate population genetic studies of P. orbicularis for conservation and applied purposes. 


\section{ACKNOWLEDGEMENTS}

This work was supported by DI-1245-16/R (Universidad Andres Bello) awarded to LC-P. The authors acknowledge language support provided by Ashley VanCott (BioPub, Chile).

\section{LITERATURE CITED}

Aranguren-Méndez JA, R Román-Bravo, W Isea, Y Villasmil \& J Jordana. 2005. Los microsatélites (STR' s), marcadores moleculares de ADN por excelencia para programas de conservación: una revisión. Archivos Latinoamericanos de Producción Animal 13(1): 1-6.

Becerra V \& M Paredes. 2000. Uso de marcadores bioquímicos y moleculares en estudios de diversidad genética. Agricultura Técnica 60: 270-281.

Blouin NA, J Brodie, AC Grossman, P Xu \& SH Brawley. 2011. Porphyra: a marine crop shaped by stress. Trends in Plant Science 16: 29-37.

Camacho C, G Coulouris, V Avagyan, N Ma, J Papadopoulos, K Bealer \& TL Madden. 2009. BLAST+: architecture and applications. BMC Bioinformatics 10:421. $<$ doi:10.1186/1471-2105-10-421>

Contreras-Porcia L, D Thomas, V Flores \& JA Correa. 2011. Tolerance to oxidative stress induced by desiccation in Porphyra columbina (Bangiales, Rhodophyta). Journal of Experimental Botany 62: 1815-1829.

Contreras-Porcia L, C López-Cristoffanini, C Lovazzano, MR Flores-Molina, D Thomas, A Núñez, C Fierro, E Guajardo, J Correa, M Kube \& R Reinhardt. 2013. Differential gene expression in Pyropia columbina (Bangiales, Rhodophyta) under natural hydration and desiccation conditions. Latin American Journal of Aquatic Research 41: 933-958.

Fierro C, C López-Cristoffanini, A Meynard, C Lovazzano, F Castañeda, E Guajardo \& L Contreras-Porcia. 2017. Expression profile of desiccation tolerance factors in intertidal seaweed species during the tidal cycle. Planta 245: 1149-1164.

Guajardo E, JA Correa \& L Contreras-Porcia. 2016. Role of abscisic acid (ABA) in activating antioxidant tolerance responses to desiccation stress in intertidal seaweed species. Planta 243: 767-781.

Guillemin M-L, L Contreras-Porcia, ME Ramírez, EC Macaya, C Bulboa-Contador, H Woods, C Wyatt \& J Brodie. 2016. The bladed Bangiales (Rhodophyta) of the South Eastern Pacific: Molecular species delimitation reveals extensive diversity. Molecular Phylogenetics and Evolution 94: 814-826.

Hulce D, X Li, T Snyder-Leiby \& CS Liu. 2011. GeneMarker ${ }^{\circledR}$ genotyping software: Tools to increase the statistical power of DNA fragment analysis. Journal of Biomolecular Techniques 22: S35-S36.
López-Cristoffanini C, J Zapata, F Gaillard, P Potin, JA Correa \& L Contreras-Porcia. 2015. Identification of proteins involved in desiccation tolerance in the red seaweed Pyropia orbicularis (Rhodophyta, Bangiales). Proteomics 15: 3954-3968.

Meglécz E, N Pech, A Gilles, V Dubut, P Hingamp, A Trilles, R Grenier \& JF Martin. 2014. QDD version 3.1: A user friendly computer program for microsatellite selection and primer design revisited: Experimental validation of variables determining genotyping success rate. Molecular Ecology Resources 14: 1302-1313.

Meynard A, J Zapata, N Salas, C Betancourtt, G PérezLara, F Castañeda, ME Ramírez, C Bulboa-Contador, ML Guillemin \& L Contreras-Porcia. 2019. Genetic and morphological differentiation of Porphyra and Pyropia species (Bangiales, Rhodophyta) coexisting in a rocky intertidal in Central Chile. Journal of Phycology 55: 297 313.

Peakall R \& PE Smouse. 2006. GENALEX 6: genetic analysis in Excel. Population genetic software for teaching and research. Molecular Ecology Notes 6: 288-295.

Peakall R \& PE Smouse. 2012. GenAlEx 6.5: genetic analysis in Excel. Population genetic software for teaching and research - an update. Bioinformatics 28: 2537-2539.

Ramírez ME, L Contreras-Porcia, M-L Guillemin, J Brodie, C Valdivia, MR Flores-Molina, A Núñez, C BulboaContador \& C Lovazzano. 2014. Pyropia orbicularis sp. nov. (Rhodophyta, Bangiaceae) based on a population previously known as Porphyra columbina from the central coast of Chile. Phytotaxa 158: 133-153.

Raymond M \& F Rousset. 1995. Genepop (version 4.2): population genetics software for exact tests and ecumenicism. Journal of Heredity 86: 248-249.

Rozen S \& H Skaletsky. 2000. Primer3 on the WWW for General Users and for Biologist Programmers. In: Misener S \& SA Krawetz (eds). Bioinformatics methods and protocols. Methods in Molecular Biology 132: 365-386. Humana Press, Totowa.

Wattier R, P Prodöhl \& C Maggs. 2000. DNA isolation protocol for red seaweed (Rhodophyta). Plant Molecular Biology Reporter 18: 275-281.

Yan XH \& M Huang. 2010. Identification of Porphyra haitanensis (Bangiales, Rhodophyta) meiosis by simple sequence repeat markers. Journal of Phycology 46: 982986.

Zuo ZH, CG Wang, XH Cao, Y Su, LJ Liao \& YX Chen. 2007. Isolation and characterization of microsatellite loci from a commercial cultivar of Porphyra haitanensis. Molecular Ecology Notes 7: 522-524. 